\title{
フランカー課題における特徵類似性と 弁別カテゴリーの影響1
}

\author{
金子 利佳 2,3 国立情報学研究所 熊田 孝恒 産業技術総合研究所 \\ 福永 克己 $^{2}$ 筑波技術大学
}

\author{
Effects of feature similarity and discrimination category in a flanker task \\ Rika Kaneko (National Institute of Informatics), Takatsune Kumada (National Institute \\ of Advanced Industrial Science and Technology), and \\ Yoshiki Fukunaga (Tsukuba University of Technology)
}

\begin{abstract}
Three experiments were conducted to investigate the effects of feature similarity and discrimination category in a flanker task. Gabor patches were used as target and distractor stimuli for each experiment. In the first experiment, the target turned to minus or plus $45 \mathrm{deg}$ from the vertical, whereas the orientation of the distractors changed between minus and plus $45 \mathrm{deg}$ by $15 \mathrm{deg}$. For the second experiment, three conditions of the target orientation were used: minus or plus $45 \mathrm{deg}$, minus $22.5 \mathrm{deg}$ or plus $67.5 \mathrm{deg}$, and 0 deg or plus $90 \mathrm{deg}$. The orientation of the distractors changed between the orientations of the two targets by $22.5 \mathrm{deg}$. In the third experiment, the target turned to minus or plus $10 \mathrm{deg}$ from the vertical, whereas the orientation of the distractors changed between minus and plus $40 \mathrm{deg}$ by $5 \mathrm{deg}$. The results showed that responses to the target were affected by the difference between the orientations of the target and the distractors as well as the category of their orientations.
\end{abstract}

Key words: flanker effect, feature similarity, stimulus orientation, discrimination category, reaction time.

The Japanese Journal of Psychology

2011, Vol. 82, No. 2, pp. 141-149

私たちはある対象だけに焦点的に注意を向けようと しても，その周辺の情報を処理してしまうことがあ る。これは, 注意を向けようとする対象の占める範囲 が狭く，しかも周辺に密に対象が呈示されているとき に起こりやすい。注意が他の対象にも同時に向けられ ると，注意を向けようとした対象の処理が遅延した り，処理を誤ったりする（Eriksen \& Eriksen, 1974, 1979)。

焦点的注意に関する代表的な研究として, Eriksen \& Eriksen（1974）の選択反応課題を用いた研究が挙 げられる。Eriksen らは，実験参加者に文字列を呈示 し，その中央に呈示される文字に対して選択反応をさ

Correspondence concerning this article should be sent to: Rika Kaneko, National Institute of Informatics, Hitotsubashi, Chiyodaku, Tokyo 101-8430, Japan (e-mail: rkaneko@nii.ac.jp)

本研究は平成 14 年度佐藤愛子学術奨励金の補助を受けて行 われた。

2 本研究は著者が産業技術総合研究所に在職中に行われた。

3 日本学術振興会特別研究員
せた。このような課題は “フランカー課題”と呼ばれ る。実験参加者にはアルファベットの $\mathrm{H}$ か $\mathrm{K}$ が呈示 されたときには一方のキーを, $\mathrm{S}$ か $\mathrm{C}$ が呈示された ときにはもう一方のキーを押すよう求めた。このとき の反応時間は, 反応刺激の左右に同じ反応に対応した 文字が呈示されたとき（例えば，KKKHKKK：反応 一致条件）に比べて，異なる反応に対応した文字が呈 示されたとき（例えば, SSSHSSS：反応不一致条件） に長くなった。この効果は “フランカー効果”と呼ば れる。もし中央の文字だけに焦点的に注意を向けるこ とができれば，周辺にどのような文字が呈示されても 反応時間に変化はないはずである。Eriksen \& Eriksen （1974）は周辺刺激にも注意が向けられたことによっ て異なる反応過程の活性が生じ，それを抑制したため に反応時間の遅延が生じたのではないかと考察してい る。

しかし，フランカー効果には反応の過程だけではな く, 周辺刺激の知覚的特徵が影響を与えることも明ら かにされている。フランカー課題において 2 種類の文 
字（例えば， $\mathrm{H}$ と S ）が一つの反応に割り当てられて いるとき, 反応一致条件では周辺刺激と反応刺激が異 なる場合（例えば, SSSHSSS) よりも，周辺刺激と 反応刺激が同じ場合（例えば, HHHHHHH）に反応 が速くなることが示されている（Eriksen \& Eriksen, 1979)。また, Eriksen \& Eriksen (1974) は, フラン カー課題において二つの反応キーのどちらにも割り当 てられていない文字刺激（以下，ニュートラル刺激と する）を周辺に呈示し，それらの文字の形態的特徵が 反応に影響を与えることを明らかにした。フランカー 課題の選択反応時間は, 反応刺激（例えば, H) と異 なる形態的特徵をもつ刺激が周辺に呈示されたとき （例えば, GJQHGJQ）よりも，類似した特徵をもつ 文字が呈示されたとき（例えば，NWZHNWZ）に短 くなる傾向があった。

フランカー課題に扔ける刺激の形態的特徵の効果を 調べることは，周辺刺激についてどのような知覚的処 理が起こっているのかを明らかにすることになる (Cohen \& Shoup, 1993)。例えば, ニュートラル刺激 が周辺に呈示されたときの反応時間が，反応刺激と周 辺刺激が同一であったときの反応時間と差がなけれ ば，観察者はニュートラル刺激を反応刺激と同じ特性 をもつ刺激と見なしていたと推測できる。逆に，周辺 刺激が異なる反応に対応していたときの反応時間と差 がなければ，ニュートラル刺激を異なる反応に対応し た刺激と見なしていたと推測できる。

フランカー課題に打ける反応刺激と周辺刺激の知覚 的特徵については，これまで主に刺激の全体的特徵に ついて検討が行われてきた。すでに述べたように，ア ルファベットの文字を刺激とする課題においては, 主 に文字を構成する線分の種類（直線や曲線）が操作さ れ，反応に及ぼす効果が調べられてきた（Eriksen \& Eriksen, 1974)。また, 記号を刺激とする場合には, 記号の種類（例えば, <, >や／、）が操作された (Cohen \& Shoup, 1993)。さらに, 図形を用いた場合 には, その図形の形（例えば，三角形や四角形）や色 が操作された（Lamberts, 1994)。しかし，いずれも 刺激の全体的特徵に関する検討であり, 反応刺激と周 辺刺激の間にどの程度の形態的差異があると反応に影 響を与えるのかなどの量的効果については明らかでは ない。しかし，最近 Rouder \& King（2003）はモーフ イングにより文字刺激の形態的特徵を段階的に操作 し, 反応刺激と周辺刺激間のコントラスト強調がフラ ンカー効果に関係することを示している。

フランカー効果における刺激の形態的特徽について は，刺激そのものの特徵だけではなく，私たちがすで に保持する認知的カテゴリーとの関連からも検討が始 められている。Fournier, Scheffers, Coles, Adamson, \& Abad（1997）は, 刺激の形態的特徵に加えて, 刺激 と反応のマッピングの効果について調べ, 反応刺激と
周辺刺激の類似性が高くなると反応刺激の評価により 時間がかかり, 矢印のように刺激と反応のマッピング 効果が強い刺激を用いた場合には反応の競合過程によ り時間がかかることを示した。こうした認知的カテゴ リーの効果は, 視覚探索課題を用いた研究でも示され ている。Wolfe, Friedman-Hill, Stewart, \& O'Connell （1992）は特定の傾き（例えば，急な傾き）をもつ夕 ーゲット刺激を探索する場合, デイストラクタ刺激が ターゲット刺激の傾きと異なるカテゴリー（例えば, 緩やかな傾き) に分類されるとき, 同じカテゴリー （急な傾き）に分類されるときょりも探索時間が短く なることを見いだしている。

本研究では, フランカー課題に打ける周辺刺激の知 覚過程について, 二つの点から検討を行った。一つ は, 周辺刺激の傾きを段階的に操作することによっ て, フランカー課題における特徴類似性の効果を定量 的に測定することであった。多くの先行研究では, 刺 激の類似性について刺激全体の特徵を操作することが 行われてきたが, 本研究では刺激の構成要素は変え ず, 反応刺激として傾きの異なる 2 種類の図形を, 周 辺刺激として反応刺激と同様の縞でさまざまな傾きの ものを用い, 反応刺激と周辺刺激の傾きの差が大きく なると反応が遅延するのかを実際に測定した。

本研究のもう一つの目的は, フランカー課題におけ る認知的カテゴリーの影響を調べることであった。本 研究では左右に傾いた図形を刺激として用いることと したが, 反応刺激として左右の方向性をもつ図形 （く，＞など）を用いると, 左右の選択反応へのマッ ピングが容易になると考えられる（Rösler \& Finger, 1993）。これは刺激を左右の方向というカテゴリーに よって弁別し，そのまま左右の反応へ対応づけられる ためだと考えられる。本研究では刺激を弁別する際の 方向のカテゴリー（以下，弁別カテゴリーとする) が，フランカー効果に及ぼす影響を検討した。もし反 応刺激だけではなく, 周辺刺激も左右の傾きによって カテゴリー化されているならば, 反応刺激と異なるカ テゴリーに分類される周辺刺激は, 傾きの差にかかわ らず，反応を遅延させやすいと予想された。

\section{実 験 1}

実験 1 では, フランカー課題を用いて, 周辺刺激と 反応刺激の傾きの違いが選択反応に及ぼす影響につい て検討した。実験課題は, 反応刺激 (ガボールパッ チ）の傾きについてできるだけ早く選択反応をするこ

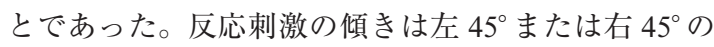
いずれかであった。反応刺激の両脇には左 $45^{\circ}$ から右 $45^{\circ}$ までの傾きをもつ周辺刺激（ガボールパッチ）が 呈示された。

先行研究の知見から, 反応刺激と同じ傾きの刺激が 周辺刺激として呈示されたときの反応時間は，もう一 
方の反応刺激が周辺刺激として呈示されたときに比べ て，短くなることが予測された。また，刺激の類似性 が反応時間に影響を及ぼすのであれば，反応が割り当 てられている左右 $45^{\circ}$ 以外の刺激（ニュートラル刺 激）については，反応刺激との傾きの差が大きくなる ほど，反応時間は増加すると予想された。

\section{方 法}

参加者 大学生 12 名が実験に参加した。全員裸眼 視力あるいは矯正視力が 0.5 以上あり, 中心視で 2 種 類の反応刺激を弁別することができた。

装置 刺激の呈示㧍よび反応の記録には, パーソナ ルコンピューター (Power Macintosh G4, 400 MHz) を用いた。刺激は 21 インチの CRT デイスプレイ (Sony トリニトロンカラーグラフィックディスプレイ GDM-F500R）に呈示された。リフレッシュレート は $100 \mathrm{~Hz}$ で, 画素数は縦 $768 \times$ 横 1024 であった。 視距離は $75 \mathrm{~cm}$ で, ディスプレイのサイズは縦 $29 \mathrm{~cm}$ ×横 $39 \mathrm{~cm}$ であり, これは視角にして縦 $16.5^{\circ} \times$ 横 $22.1^{\circ}$ に対応した。

刺激 実験刺激として, 空間周波数 3 cycle/ degree, コントラスト 1 のガボールパッチ（エンベロープの $\sigma$ は $0.73^{\circ}$ )を用いた。反応刺激の縞の傾きは 2 種類あ り，一方は垂直から時計回りに $45^{\circ}$ (右 $45^{\circ}$ あいは $+45^{\circ}$ ), もう一方は反時計回りに $45^{\circ}$ (左 $45^{\circ}$ るい は-45 ) 傾いていた。周辺刺激の縞の傾きは, 左 $45^{\circ}$ から右 $45^{\circ}$ まで $15^{\circ}$ 刻みのいずれかの傾きであっ た。

実験計画 反応刺激には右 $45^{\circ}$ と左 $45^{\circ}$ の 2 種類の 傾きがあった。周辺刺激は反応刺激との傾きの差で定 義され，それぞれの反応刺激に対して $0^{\circ}$ (その刺激 と同じ傾き）から $90^{\circ}$ (もう一方の反応刺激と同じ傾

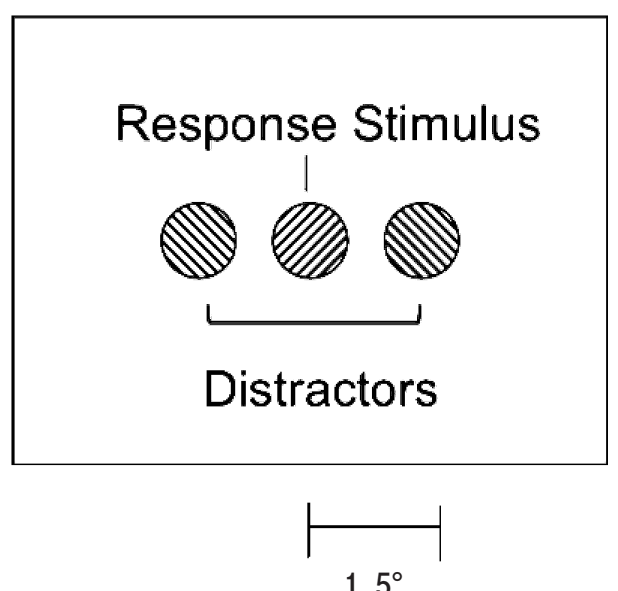

Figure 1. Layout of response stimulus and distractors in Experiment 1.
き）まで 7 種類あった。

手続き まず, 参加者の実験開始のキー入力によ り, 画面中央に固視点 $\left(\right.$ 十字, $\left.1.0^{\circ} \times 1.0^{\circ}\right)$ が呈示さ れた。 $1.1 \mathrm{~s}$ から $1.3 \mathrm{~s}$ 後に固視点が消え, その位置に 反応刺激が $0.1 \mathrm{~s}$ 呈示された。また同時に反応刺激の 左右に周辺刺激が一つずつ呈示された（Figure 1)。 反応刺激と周辺刺激の中心間距離は $1.5^{\circ}$ であった。 また左右の周辺刺激は常に同じ傾きであった。この 後, 参加者が反応キーを押すまでチェッカーボード模 様のマスク刺激が反応刺激と周辺刺激の位置に呈示さ れた。参加者の課題は, 画面中央に呈示される反応刺 激の傾きに応じて, 手元の二つのキーのどちらかをで きるだけ速く，正確に押すことであった。2 種類の反 応刺激と左右のキーの対応については, 参加者間でカ ウンターバランスをとった。各試行の反応時間と選択 反応の正誤が記録された。各参加者は課題を 7 ブロッ クに分けて行い, ブロック間で適宜休覣を取った。1 ブロックは, 112 試行から成り, 2 種類の反応刺激と 7 種類の周辺刺激が組み合わされ，それぞれ 8 試行ず つランダムな順序で呈示された。参加者は, 本試行に 先立って, 20 試行の練習を行った。参加者は, 課題 遂行中は着席し，頭部をあご台で支えられた。

\section{結 果}

各参加者について, 反応刺激と周辺刺激の角度差ご とに平均反応時間と選択反応のエラー率を計算した。 反応時間が $0.1 \mathrm{~s}$ 以下あるいは $1 \mathrm{~s}$ 以上の試行ははず れ值として分析から除外した。

Figure 2 に 2 種類の反応刺激に対する正反応の平 均反応時間を反応刺激と周辺刺激との傾きの差の関数 として示す。平均反応時間は, 反応刺激による違いは 見られず，反応刺激と周辺刺激の傾きが等しいときに

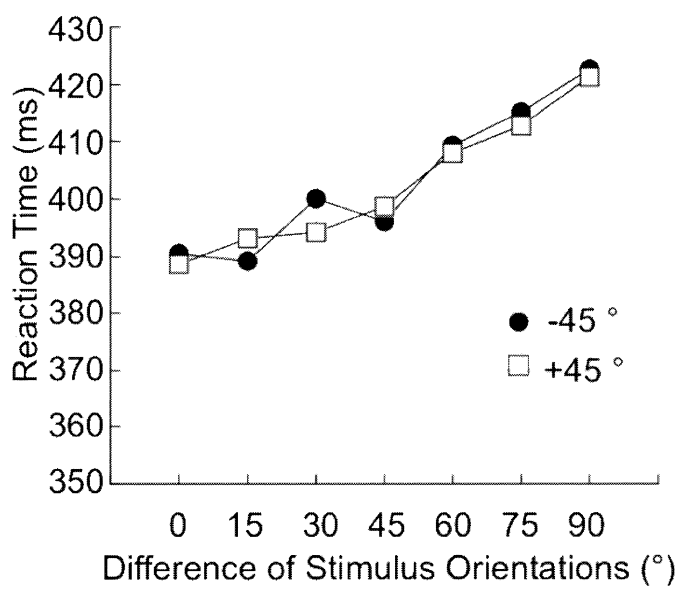

Figure 2. Mean reaction times as a function of the difference between the orientations of the target and the distractors in Experiment 1. 
Table 1

Mean error rates (\%) in Experiment 1

\begin{tabular}{cccccccc}
\hline \multirow{2}{*}{ Target } & \multicolumn{8}{c}{ Difference of Stimulus Orientations $\left(^{\circ}\right)$} \\
& 0 & 15 & 30 & 45 & 60 & 75 & 90 \\
\hline$-45^{\circ}$ & 2.61 & 3.48 & 3.83 & 2.44 & 5.04 & 6.44 & 7.51 \\
$+45^{\circ}$ & 2.80 & 1.74 & 2.09 & 2.96 & 5.74 & 6.61 & 6.79 \\
\hline
\end{tabular}

短くなり，異なる反応に対応した周辺刺激が呈示され たときに長くなった。またニュートラル刺激が周辺に 呈示されたときの反応時間は, 反応刺激との傾きの差 が大きくなるほど増加する傾向が見られた。

反応時間について, 反応刺激 (2 水準) と周辺刺激 (7 水準) の 2 要因の分散分析を行った。その結果, 反応刺激の主効果と交互作用は有意ではなかったが, 周辺刺激の主効果が有意であり, 反応刺激と周辺刺激 の傾きに差があるとき, 反応時間が長くなった $(F(6,66)=21.31, p<.001)$ 。

次に, 反応時間と周辺刺激の関係を調べるために傾 向検定を行った。反応刺激の主効果が有意ではなかっ たため, 左 $45^{\circ}$ と右 $45^{\circ}$ の結果をまとめて検定を行っ た。もし弁別カテゴリーが反応に影響を与えるのであ れば, 反応時間の変化は線形にはならず, 2 次以上の 成分が有意になると予想された。もし反応刺激と周辺 刺激の傾きの差が反応時間に与える影響が直線的なら ば, 1 次の成分が有意になると予想された。また反応 刺激と周辺刺激の傾きの差が反応時間に与える影響が 非線形ならば，2 次以上の成分も有意になると予想さ れた。検定の結果, 傾きの差の 1 次の成分が有意であ った $(F(1,11)=48.31, p<.001)$ 。またより高次の成 分は有意ではなかったが， 2 次の成分が $5 \%$ 水準で有 意に近かった $(F(1,11)=4.70, p<.053)$ 。このことか ら, 周辺刺激の効果による変動は, ほぼ直線的である が，曲線的成分も含まれる可能性があることが示唆さ れた。

エラー率はおおむね 10\%以下であった（Table 1)。 エラー率についても, 反応刺激と周辺刺激の 2 要因の 分散分析を行った。その結果, 反応刺激の主効果と交 互作用は有意ではなかったが，周辺刺激の主効果が有 意であり，反応刺激と周辺刺激の傾きに差があると き, エラー率が高くなった $(F(6,66)=6.49, p<.001) 。$ 反応の速度と正確さのトレードオフは見られなかった。

\section{考察}

実験 1 では, フランカー課題を用いて, 周辺刺激と 反応刺激の傾きの違いが反応に及ぼす効果について調 べた。その結果, 反応刺激と周辺刺激の傾きの差が大 きいときには, 傾きの差が小さいときに比べて反応時 間が長くなった。先行研究（Eriksen \& Eriksen, 1974） では, 刺激の類似性は反応刺激と周辺刺激を構成する
成分の異同を意味していたが，実験 1 では，反応刺激 と周辺刺激を構成する成分は同一であり，傾きのみが 異なっていた。したがって, この結果は, フランカー 課題において周辺刺激の構成成分の違いだけでなく, 傾きも知覚され，反応に影響を及ぼすことを示してい る。

実験 1 では, 周辺刺激の傾きを $15^{\circ}$ 刻みで変化さ せ, 反応刺激と周辺刺激の傾きの差が反応に及ぼす影 響を調べた。その結果, 反応時間は反応刺激と周辺刺 激との傾きの差に対して，ほぼ直線的に増加した。ま た, 傾向検定の結果, 反応時間の変化の 2 次の成分が 有意に近かった。このことは, 傾きの差に応じて反応 時間に及ぼす影響の大きさが変化する, あるいは傾き の差以外の要因が反応時間に影響を与えている可能性 を示唆している。この傾きの差以外の要因としては, 傾きの弁別カテゴリーの影響が考えられる。例えば, 左 $45^{\circ}$ の反応刺激に対して, 同じ左側に傾いている周 辺刺激よりも右に傾いている周辺刺激のほうが反応を 遅延させやすいならば，垂直を境にして反応時間に大 きく変化が生じ， 2 次以上の成分が有意になると考え られる。弁別カテゴリーの効果についてはさらに実験 2 で検討することとした。

\section{実 験 2}

実験 2 では, 反応刺激と周辺刺激の傾きの量的差に 加えて, 反応刺激と周辺刺激の弁別カテゴリーの異同 が反応に及ぼす影響について検討した。

すでに述べたように，反応刺激として左右の方向性 をもつ図形を用いると, 左右の選択反応へのマッピン グが容易になると考えられている（Rösler \& Finger, 1993)。これは刺激を左右のカテゴリーで弁別し，そ のまま左右の反応へ対応づけられるためと予想され る。もし反応刺激を左右のカテゴリーに分けて弁別し ているのであれば，周辺刺激が反応刺激と同一である 場合と比べて, 反応刺激のカテゴリーと同じカテゴリ 一に属す周辺刺激は, 反応を遅延させにくく, 異なる カテゴリーに属す周辺刺激は反応を遅延させやすくな ると考えられる。

実験 2 では，反応刺激を垂直を境として弁別できる 条件とできない条件を用いて, 反応刺激の弁別カテゴ リーが周辺刺激からの効果に及ぼす影響について検討 した。具体的には実験 1 と同じ左 $45^{\circ}$ と右 $45^{\circ}$ の 2 種 類の縞を反応刺激とする条件 $\left(45^{\circ}\right.$ 条件) のほか, 左 $22.5^{\circ}$ と右 $67.5^{\circ}$ の縞を反応刺激とする条件 $\left(22.5^{\circ}\right.$ 条 件) と, 垂直 $\left(0^{\circ}\right)$ と水平 $\left(90^{\circ}\right)$ の縞を反応刺激と する条件 $\left(0^{\circ}\right.$ 条件 $)$ でフランカー課題を行った。周辺 刺激は， 2 種類の反応刺激を両端の傾きとする 5 種類 の縞刺激とした。もし垂直を境に刺激が弁別され，反 応刺激と周辺刺激の弁別カテゴリーの異同が反応に影 響を与えるならば，垂直を境に反応刺激と異なる側の 
傾きをもつ周辺刺激が呈示されたときに反応が大きく 遅延すると考えられた。例えば, $22.5^{\circ}$ 条件で左 $22.5^{\circ}$ を反応刺激とするとき, 左側に傾いた周辺刺激が呈示 されたときに比べて，右側に傾いた周辺刺激が呈示さ れたときに反応時間が大きく増加すると考えられた。

また $0^{\circ}$ 条件では，反応刺激を垂直を境とする左右の カテゴリーで弁別しにくいため, 傾きの差のみが反応 に影響を及ぼすと考えられた。一方，反応刺激の弁別 カテゴリーが周辺刺激の知覚に影響を与えないなら ば, どの条件でも反応刺激との傾きの差のみが反応に 影響を与えると予想された。

\section{方 法}

参加者 大学生 12 名が実験に参加した。実験の参 加者は全員裸眼視力あるいは矯正視力が 0.5 以上あり, 中心視で 2 種類の反応刺激を弁別することができた。

装置と刺激 実験装置は実験 1 と同じであった。刺 激は, 実験 1 と同じガボールパッチを用いた。反応刺 激の組み合わせには 3 条件あり，それぞれ縞の傾きが 左 $45^{\circ}$ と右 $45^{\circ}$, 左 $22.5^{\circ}$ と右 $67.5^{\circ}, 0^{\circ}$ と $90^{\circ}$ であっ た。周辺刺激の縞の傾きは, 反応刺激の傾きを両端と する 5 種類で, $22.5^{\circ}$ 刻みのいずれかの傾きであった。

実験計画 反応刺激の組み合わせが 3 種類 $\left(45^{\circ}\right.$, $22.5^{\circ}, 0^{\circ}$ 条件) あり, 反応刺激と周辺刺激の傾きの 差が 5 種類 $\left(0^{\circ}, 22.5^{\circ}, 45^{\circ}, 67.5^{\circ}, 90^{\circ}\right)$ あった。

手続き 実験手続きは, 実験 1 とほぼ同じであった が, 実験 2 ではひとりの参加者がすべての反応刺激の 組み合わせで課題を行った。これら 3 条件の順序は参 加者間でカウンターバランスをとった。それぞれの反 応刺激の組み合わせにつき7ブロックあり，各ブロッ クでは, 2 種類の反応刺激について 5 種類の周辺刺激 が組み合わされ，それぞれ 10 試行ずつ合計 100 試行 がランダムな順序で呈示された。それぞれの反応刺激 の組み合わせでの本試行に先立って, 20 試行の練習 を行った。

\section{結 果}

各参加者について, 反応刺激の組み合わせごとに平 均反応時間と選択反応のエラー率を計算した。はずれ 值は実験 1 と同じ方法で分析から除外した。

Figure 3 に 2 種類の反応刺激に対する正反応の平 均反応時間を反応刺激の組み合わせごとに反応刺激と 周辺刺激の傾きの差の関数として示す。すべての反応 刺激の組み合わせにおいて, 反応刺激と周辺刺激の傾 きが等しいときの反応時間は, 異なる反応に対応した 周辺刺激が呈示されたときに比べて短くなった。また ニュートラル刺激が呈示されたときの反応時間は，反 応刺激との傾きの差が大きくなるほど増加する傾向が 見られた。

反応時間について, 反応刺激の組み合わせごとに, (a)

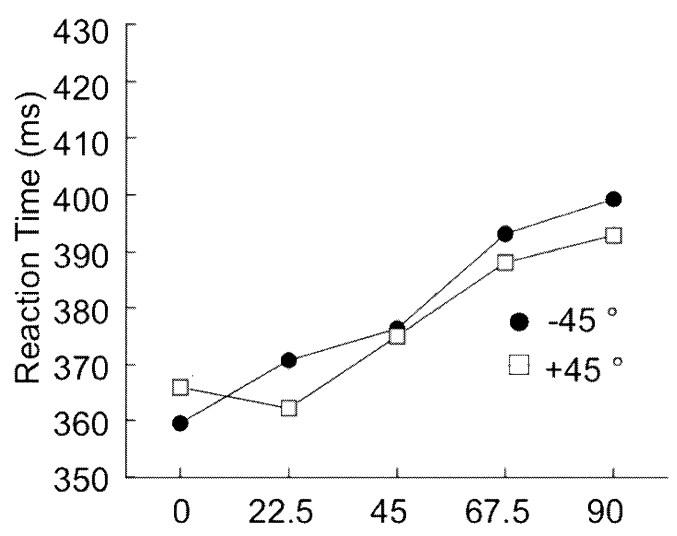

Difference of Stimulus Orientations $\left({ }^{\circ}\right)$ (b)

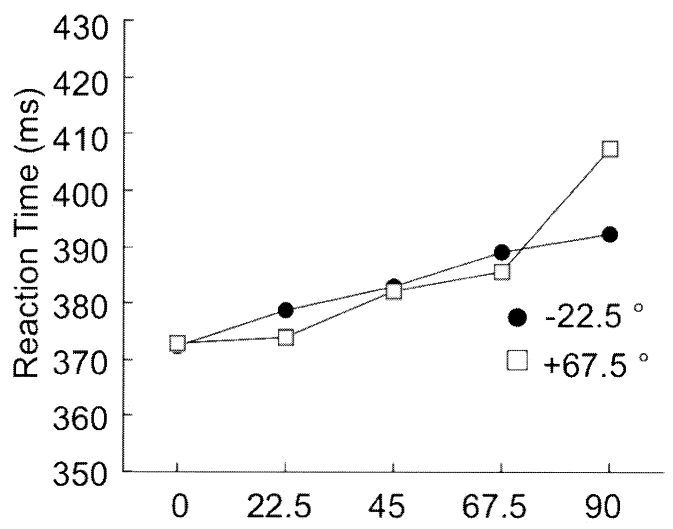

Difference of Stimulus Orientations $\left({ }^{\circ}\right)$ (c)

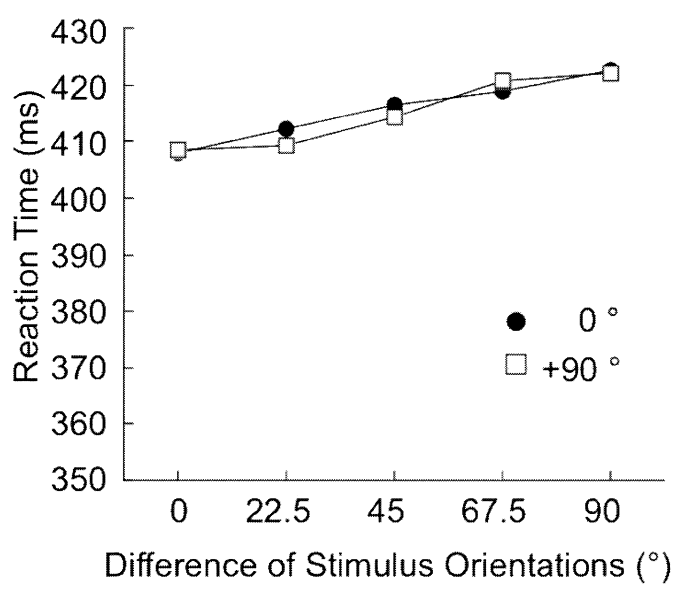

Figure 3. Mean reaction times as a function of the difference between the orientations of the target and the distractors in Experiment 2: Condition $45^{\circ}$ (a), 22. $5^{\circ}$ (b), and $0^{\circ}(\mathrm{c})$. 
反応刺激 (2 水準) と周辺刺激 (5 水準) の 2 要因の分 散分析を行った。 $45^{\circ}$ 条件の反応時間については, 反 応刺激の主効果は有意ではなかったが, 周辺刺激の主 効果と交互作用が有意であった（周辺刺激， $F(4,44)$ $=39.24, p<.001$; 交互作用, $F(4,44)=3.85, p<.01)$ 。 そこで, 周辺刺激ごとに反応刺激の単純主効果を分析 したところ，すべての周辺刺激において単純主効果は 有意ではなかった $(p>.05)$ 。また左 $45^{\circ}$ と右 $45^{\circ}$ の結 果についてそれぞれ傾向検定を行った結果, 左 $45^{\circ} に$ ついては周辺刺激の 1 次と 4 次の成分が有意であった (1 次, $F(1,11)=56.36, p<.001 ; 4$ 次, $F(1,11)=6.48$, $p<.05)$ 。一方, 右 $45^{\circ}$ については周辺刺激の 1 次か ら 3 次の成分がすべて有意であった（1 次, $F(1,11)$ $=28.38, p<.001 ; 2$ 次, $F(1,11)=6.80, p<.05 ; 3$ 次, $F(1,11)=9.05, p<.05)$ 。このことから, 周辺刺激に よる変動は直線的もしくは曲線的であることが明らか になった。

$22.5^{\circ}$ 条件の反応時間については, 反応刺激の主効果 は有意ではなかったが, 周辺刺激の主効果と交互作用 が有意であった (周辺刺激, $F(4,44)=48.06, p<.001$; 交互作用, $F(4,44)=9.10, p<.001)$ 。そこで, 周辺刺 激ごとに反応刺激の単純主効果を分析したところ, 反 応刺激と周辺刺激の傾きの差が $90^{\circ}$ のときのみ反応刺 激の単純主効果が有意であり, 反応刺激が右 $67.5^{\circ}$ の とき左 $22.5^{\circ}$ のきよりも反応時間が長くなった $(p<.01)$ 。また傾向検定を行った結果, 反応刺激が左 $22.5^{\circ}$ のとき, 周辺刺激の 1 次の成分のみが有意であ った $(F(1,11)=37.04, p<.001)$ 。のことから, 反 応刺激が左 $22.5^{\circ}$ のとき, 周辺刺激の効果による変動 は直線的であることが明らかになった。一方, 反応刺 激が右 $67.5^{\circ}$ のとき，1 次，2 次抒よび 4 次の成分が 有意であった (1 次, $F(1,11)=123.40, p<.001 ; 2$ 次, $F(1,11)=30.49, p<.001 ; 4$ 次, $F(1,11)=6.04, p<$ $.05)$ 。このことから, 反応刺激が右 $67.5^{\circ}$ のとき, 反 応時間の変化には曲線的な成分が含まれることが明ら かになった。

$0^{\circ}$ 条件の反応時間については, 反応刺激の主効果と 交互作用は有意ではなかったが, 周辺刺激の主効果が 有意であり, 反応刺激と周辺刺激の傾きに差があると き, 反応時間が長くなった $(F(4,44)=9.54, p<.001)$ 。 また $0^{\circ}$ と右 $90^{\circ}$ の結果をまとめて傾向検定を行った結 果, 周辺刺激の 1 次の成分のみが有意であった $(F(1,11)=27.79, p<.001)$ 。このことから, 周辺刺激 による変動は直線的であることが明らかになった。

エラー率は抒㧍む㸚 $10 \%$ 以下であった（Table 2)。 エラー率についても, 反応刺激の組み合わせごとに反 応刺激と周辺刺激の 2 要因の分散分析を行った。 $45^{\circ}$ 条件では, 反応刺激の主効果と交互作用は有意ではな かったが, 周辺刺激の主効果が有意であり, 反応刺激 と周辺刺激の傾きに差があるとき，エラー率が高くな
Table 2

Mean error rates (\%) in Experiment 2

\begin{tabular}{|c|c|c|c|c|c|}
\hline \multirow{2}{*}{ Target } & \multicolumn{5}{|c|}{ Difference of Stimulus Orientations $\left(^{\circ}\right)$} \\
\hline & 0 & 22.5 & 45 & 67.5 & 90 \\
\hline \multicolumn{6}{|c|}{ Condition $45^{\circ}$} \\
\hline$-45^{\circ}$ & 1.55 & 1.31 & 2.50 & 4.76 & 6.55 \\
\hline$+45^{\circ}$ & 1.90 & 1.79 & 3.57 & 7.14 & 6.31 \\
\hline \multicolumn{6}{|c|}{ Condition $22.5^{\circ}$} \\
\hline$-22.5^{\circ}$ & 1.55 & 1.55 & 4.52 & 5.00 & 6.19 \\
\hline$+67.5^{\circ}$ & 1.79 & 1.90 & 2.98 & 1.79 & 9.17 \\
\hline \multicolumn{6}{|c|}{ Condition $0^{\circ}$} \\
\hline $0^{\circ}$ & 3.93 & 3.21 & 6.31 & 7.26 & 7.50 \\
\hline$+90^{\circ}$ & 1.55 & 3.69 & 4.64 & 6.55 & 6.67 \\
\hline
\end{tabular}

った $(F(4,44)=31.73, p<.001)$ 。22.5 条件のエラー 率については, 反応刺激の主効果は有意ではなかった が，周辺刺激の主効果と交互作用が有意であった（周 辺刺激, $F(4,44)=14.71, p<.001$; 交互作用, $F(4,44)$ $=4.24, p<.01)$ 。そこで周辺刺激ごとに反応刺激の単 純主効果を分析したところ, 反応刺激と周辺刺激の傾 きの差が $67.5^{\circ}$ のとき, 反応刺激が右 $67.5^{\circ}$ に比べて 反応刺激が左 $22.5^{\circ}$ のときにエラー率が高くなった $(p<.05)$ 。 $0^{\circ}$ 条件のエラー率については, 反応刺激の 主効果と交互作用は有意ではなかったが，周辺刺激の 主効果が有意であり, 反応刺激と周辺刺激の傾きに差 があるとき，エラー率が高くなった $(F(4,44)=9.57$, $p<.001)$ 。反応の速度と正確さのトレードオフは見ら れなかった。

\section{考 察}

実験 2 では, 反応刺激と周辺刺激の傾きの差に加え て弁別カテゴリーの異同が反応に及ぼす効果について 検討した。

$0^{\circ}$ 条件については, $45^{\circ}$ 条件打よび $22.5^{\circ}$ 条件と異 なり, 全般に反応時間が長くなる傾向が見られた。反 応の遅延の要因としては, 刺激と反応のマッピングの 難しさが考えられる。 $0^{\circ}$ 条件では, 垂直, 水平方向の 刺激を反応刺激として用いたために, 左右の反応への マッピングが難しかった。一方, $45^{\circ}$ 条件と $22.5^{\circ}$ 条 件では, 左右のカテゴリーで弁別できる刺激を反応刺 激として用いたために, 左右の反応へのマッピングが 容易だった。別の要因としては, 反応刺激と周辺刺激 の間の側方相互作用の可能性がある。低コントラスト のガボールパッチの検出は, 同方向の方位をもつガボ ールパッチがフランカーとして共線的に呈示されたと きに促進されることが明らかにされている（Polat \& Sagi, 1993)。 $0^{\circ}$ 条件では, 他の条件と異なり, 反応刺 激と周辺刺激が共線的に呈示される試行 $\left(90^{\circ}\right.$ の反応 刺激と $90^{\circ}$ の周辺刺激の組み合わせ）が含まれてい 
た。しかし，この組み合わせの時の反応時間は共線的 ではない刺激の組み合わせ $\left(0^{\circ}\right.$ の反応刺激と $0^{\circ}$ の周 辺刺激の組み合わせ）のときの反応時間と比べて差が なかった。したがって実験 2 において側方相互作用が 生じていたために, 他の条件に比べて反応時間が長く なった可能性は低いと考えられる。

$0^{\circ}$ 条件の反応時間について傾向検定を行った結果, 周辺刺激の 1 次の成分のみが有意であった。このこと は反応時間の変化に反応刺激と周辺刺激の傾きの差が 影響していることを示唆するとともに, その変化が直 線的であることを示している。

$45^{\circ}$ 条件の反応時間については, 傾向検定の結果, 曲線成分が有意であることが示された。この結果だけ では, これが弁別カテゴリーの影響なのか, 反応刺激 と周辺刺激の傾きの差の影響が非線形なのかは判断で きない。しかし， $0^{\circ}$ 条件における傾きの差の影響が直 線的であったことから考えると，45条件における傾 きの差の効果も直線的である可能性が高い。したがっ

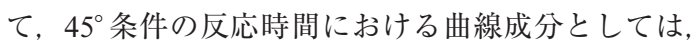
“傾きの差以外の要因”，すなわち弁別カテゴリーが影 響を与えていたことが考えられる。

$22.5^{\circ}$ 条件については, 傾向検定の結果, 反応刺激 が右 $67.5^{\circ}$ のきに曲線成分が有意だった。このこと は $45^{\circ}$ 条件と同様に，傾きの差だけでなく，弁別カテ ゴリーも影響していたことが考えられる。一方，反応 刺激が左 $22.5^{\circ}$ の場合, 反応時間には直線成分のみが 含まれた。このように左右の反応刺激で結果が異なっ た要因として, 周辺刺激の呈示頻度の効果が考えられ る。 $22.5^{\circ}$ 条件の周辺刺激は垂直を境に右に傾いてい るものが左に傾いているものよりも多かった。そのた め右 $67.5^{\circ}$ の反応刺激に対して, 右に傾いた周辺刺激 が呈示される頻度が高く，左に傾いた周辺刺激が呈示 される頻度が低かった。フランカー課題では, 反応一 致試行の頻度が反応不一致試行よりも高いときにフラ ンカー効果が強まることが明らかにされている (Gratton, Coles, \& Donchin, 1992)。左 $22.5^{\circ}$ と右 $67.5^{\circ}$ の反応刺激ではフランカー効果の強さに違いがあり,

これが弁別カテゴリーの効果に影響を与えたのではな いかと考えられる。

弁別カテゴリーの境界については, 傾向検定の結果 から推測することはできないが， $0^{\circ}$ 条件で弁別カテゴ リーの効果が見られず，垂直を挟んで反応刺激を弁別 できる $45^{\circ}$ 条件と $22.5^{\circ}$ 条件で見られたことから，垂 直付近がカテゴリーの境界ではないかと考えられる。

\section{実 験 3}

これまでの検討で弁別カテゴリーの効果が必ずしも 明確ではなかった理由として, 周辺刺激の分布範囲が 限られていたことが考えられる。実験 1 と実験 2 の周 辺刺激は 2 種類の反応刺激の傾きを両端とする $90^{\circ} の$
範囲内にのみ分布していた。

そこで実験 3 では，反応刺激の傾きの差を $20^{\circ}$ に狭 めると同時に周辺刺激の分布範囲を拡大することによ り, カテゴリーの効果と周辺刺激の効果を詳細に検討 できるようにした。周辺刺激には 2 種類の反応刺激の 内側の傾きだけではなく，2 種類の反応刺激の外側の 傾きを加えた。これにより，反応刺激との傾きの差は 同じでも，もう一方の反応刺激に対して近づく方向の 傾きと離れる方向の傾きの周辺刺激が呈示されること となった。もし反応刺激を境としたカテゴリーによっ て周辺刺激の影響が異なるのであれば，ある刺激に対 する反応は，傾きの差が同じとき，周辺刺激がもう一 方の反応刺激から遠ざかる方向に傾いているときのほ うが, 近づく方向に傾いているときよりも速くなると 考えられた。

\section{方 法}

参加者 大学生 21 名が実験に参加した。全員裸眼 視力あるいは矯正視力が 0.5 以上あり, 中心視で 2 種 類の反応刺激を弁別することができた。

装置 実験装置は実験 1 と同様であったが，2名を 同時に実験できるよう，1名ずつ簡易暗室内で実験を 行った。刺激の呈示および反応の記録には, パーソナ ルコンピューター (Mac Book Pro, 2. 16 GHz, PowerPC G5, 2.5GHz) を用いた。刺激は 21 インチの CRT ディスプレイ (Sony GDM-F500R, iiyama MT8521-E）に呈示された。

刺激 実験 1 と同じガボールパッチを用いた。反応 刺激は, 縞の傾きが左 $10^{\circ}$ と右 $10^{\circ}$ の 2 種類であった。 また周辺刺激の縞の傾きは左 $40^{\circ}$ から右 $40^{\circ}$ まで $5^{\circ}$ 刻 みのいずれかの傾きであった。

実験計画 反応刺激は左 $10^{\circ}$ と右 $10^{\circ}$ の 2 種類の傾 きがあった。周辺刺激は左 $40^{\circ}$ から右 $40^{\circ}$ まで 17 種類 の傾きがあった。

手続き 実験手続きは, 実験 1 と同様であった。各 参加者は課題を 7 ブロックに分けて行い, ブロック間 で適宜休憩を取った。1ブロックは，272試行から成 り, 2 種類の反応刺激と 17 種類の周辺刺激が組み合 わされ，それぞれ 8 試行ずつランダムな順序で呈示さ れた。参加者は, 本試行に先立って, 20 試行の練習 を行った。

\section{結 果}

21 名が実験に参加したが, 課題を誤って理解し周 辺刺激について反応した者 2 名と，実験を完遂できず デー夕数が不十分であった者 1 名を分析から除外し，

18 名の結果について分析を行った。各参加者につい て, 反応刺激と周辺刺激の角度差ごとに平均反応時間 と選択反応のエラー率を計算した。はずれ值は実験 1 と同じ方法で分析から除外した。 
Figure 4 に反応刺激に対する正反応の平均反応時 間を, 反応刺激と周辺刺激との傾きの差の関数として 示す。反応刺激の傾きを基準として, 周辺刺激が反応 刺激と等しいとき，もう一つの反応刺激に近づく方向 の傾きのとき，離れる方向の傾きのときの三つに分け て示す。

全般に, 反応刺激と周辺刺激の傾きが等しいときの 反応時間は短くなり, 反応刺激と周辺刺激の傾きの差 が大きくなるほど反応時間は増加する傾向が見られ た。これは実験 1 と実験 2 の結果と一致するものであ った。また反応時間は周辺刺激が反応刺激を基準にど ちら側に傾いているかによって異なった。

反応時間について, 周辺刺激の傾きの方向 (2 水 準) と反応刺激と周辺刺激との傾きの差 $\left(5^{\circ}\right.$ から $30^{\circ}$ まで 6 水準）の 2 要因の分散分析を行った。その結 果, 周辺刺激の傾きの方向と傾きの差の主効果と交互 作用が有意であった（周辺刺激の方向， $F(1,17)=$ $19.62, p<.001$; 傾きの差, $F(5,85)=44.53, p<.001$; 交互作用， $F(5,85)=3.25, p<.05)$ 。そこで, 傾きの 差ごとに周辺刺激の方向の単純主効果を分析したとこ ろ, すべての傾きの差で周辺刺激の方向の効果が有意 であり，傾きの差が同じとき，周辺刺激がもう一つの 反応刺激から離れる方向の傾きょりも，もう一つの反 応刺激に近づく方向の傾きのときに反応時間が長くな った $(p<.05)$ 。

エラー率は㧍扮むね $15 \%$ 以下であった（Table 3)。 エラー率についても, 周辺刺激の傾きの方向 (2水 準) と反応刺激と周辺刺激との傾きの差 $\left(5^{\circ}\right.$ から $30^{\circ}$ まで 6 水準) の 2 要因の分散分析を行った。その結 果, 周辺刺激の傾きの方向の主効果は有意ではなかっ たが，傾きの差の主効果と交互作用が有意であった (傾きの差, $F(5,85)=18.06, p<.001$; 交互作用, $F(5,85)=8.82, p<.001)$ 。そこで傾きの差ごとに周辺

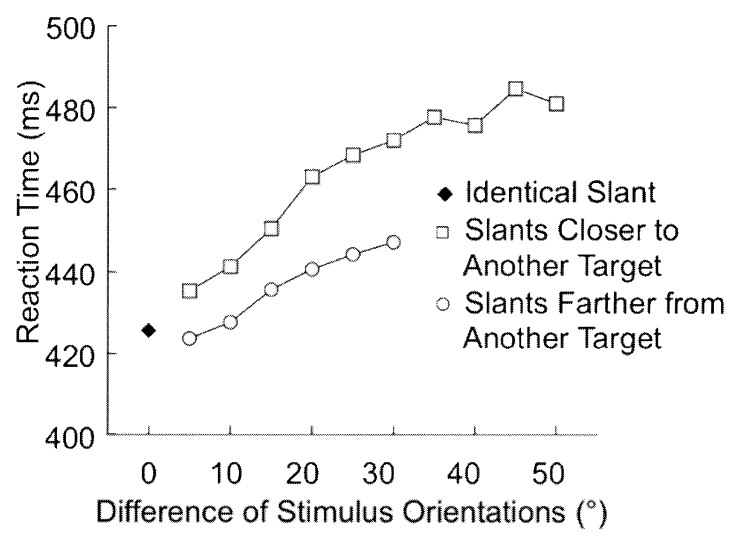

Figure 4. Mean reaction times as a function of the difference between the orientations of the target and the distractors in Experiment 3.
Table 3

Mean error rates (\%) in Experiment 3

\begin{tabular}{|c|c|c|c|c|c|}
\hline \multirow{2}{*}{ Distractor } & \multicolumn{5}{|c|}{ Difference of Stimulus Orientations $\left(^{\circ}\right)$} \\
\hline & 5 & 10 & 15 & 20 & 25 \\
\hline $\begin{array}{l}\text { Farther from } \\
\text { Another Target }\end{array}$ & 4.39 & 5.11 & 5.89 & 5.92 & 7.25 \\
\hline $\begin{array}{l}\text { Closer to } \\
\text { Another Target }\end{array}$ & 3.50 & 3.58 & 6.58 & 7.81 & 8.17 \\
\hline & 30 & 35 & 40 & 45 & 50 \\
\hline $\begin{array}{l}\text { Farther from } \\
\text { Another Target }\end{array}$ & 5.58 & - & - & - & - \\
\hline $\begin{array}{l}\text { Closer to } \\
\text { Another Target }\end{array}$ & 10.75 & 11.44 & 13.22 & 14.17 & 13.03 \\
\hline
\end{tabular}

Note. When the distractor's slant was identical to the response stimulus, mean error rate was 3.89 .

刺激の方向の単純主効果を分析したところ, 傾きの差 が $5^{\circ}$ と $30^{\circ}$ のときに周辺刺激の方向の効果が有意であ り，傾きの差が $5^{\circ}$ のきは，もう一つの反応刺激に 近づく方向の傾きよりも，もう一つの反応刺激から遠 ざかる方向の傾きのときにエラー率が高くなり，傾き の差が $30^{\circ}$ のときは，もう一つの反応刺激から遠ざか る方向の傾きよりも，もう一つの反応刺激に近づく方 向の傾きのときにエラー率が高くなった $(p<.05)$ 。 反応の速度と正確さのトレードオフは見られなかった。

\section{考 察}

実験 3 では，周辺刺激と弁別カテゴリーが反応に及 ぼす効果について, 周辺刺激の分布範囲を拡大して検 討した。その結果, 反応時間は反応刺激と周辺刺激の 傾きの差に応じて増加する傾向が見られた。また，反 応時間は，周辺刺激が反応刺激を基準にどちら側に呈 示されるかによっても変化した。周辺刺激がもう一つ の反応刺激から離れる方向に傾いていると反応時間が 全般に短くなり，もう一つの反応刺激に近づく方向に 傾いていると反応時間が全般に長くなった。もし反応 刺激と周辺刺激の傾きの差のみが反応に影響を与える のであれば，すべての周辺刺激で反応は傾きの差に応 じて変化するはずである。したがって，この結果は周 辺刺激がカテゴリー化されて処理され, 反応に影響を 与えていることを示している。もう一つの反応刺激か ら離れる方向の傾きをもつ周辺刺激は, 反応刺激との 特徴類似性がより高いと見なすことができる。

実験 3 の結果からは, 実験 3 で用いられた弁別カテ ゴリーは実験 2 で示されたような垂直を境とするもの ではないことが推測される。例えば, 左 $10^{\circ}$ の反応刺 激に対して, 左 $5^{\circ}$ の周辺刺激は垂直をカテゴリーの 境と仮定すると反応刺激と同じカテゴリーに属すが, 
反応時間は左 $15^{\circ}$ の周辺刺激よりも明らかに長くなっ た。同様に, $0^{\circ}$ の周辺刺激の反応時間も明らかに左 $20^{\circ}$ よりも長くなった。もし垂直を境として周辺刺激 がカテゴリー化されているのであれば，これらの周辺 刺激が呈示されたときの反応時間に差は見られないは ずである。したがって, 実験 3 では 2 種類の反応刺激 それぞれを境としてカテゴリー化されていたと考えら れる。

\section{総 合 考察}

本研究では, フランカー課題における反応刺激と周 辺刺激の類似性の効果と弁別カテゴリーの効果を刺激 の傾きを操作することによって検討した。その結果, 反応刺激と周辺刺激の傾きの差が大きいときに，傾き の差が小さいときよりも反応時間が長くなった。この ことは, 反応刺激と周辺刺激の傾きの類似性が刺激の 形態の類似性と同様の効果をもつことを示すものであ る。

また, 本研究では反応刺激の組み合わせや周辺刺激 の分布範囲を変えることによって, 眓形の弁別カテゴ リーが選択反応に影響を与えることを見いだした。し かし, 実験 2 と実験 3 の結果からは, 弁別カテゴリー の境がそれぞれの実験で異なることが推測された。実 験 2 では垂直を, 実験 3 では反応刺激を基準として, その影響が生じていることが示唆された。どのような 要因が弁別カテゴリーの内容の違いを生じさせている のかについては, 本研究の結果からは明らかではない が, 実験 2 と実験 3 では, 刺激の傾きや分布の範囲な どが異なっていた。これらが反応に影響を与えたこと が考えられる。

\section{引用文献}

Cohen, A., \& Shoup, R. E. (1993). Orientation asymmetry in the flanker task. Perception and Psy- chophysics, 53, 693-703.

Eriksen, B. A., \& Eriksen, C. W. (1974) . Effects of noise letters upon the identification of a target letter in a nonsearch task. Perception and Psychophysics, 16, 143-149.

Eriksen, C. W., \& Eriksen, B. A. (1979). Target redundancy in visual search: Do repetitions of the target within the display impair processing? Perception and Psychophysics, 26, 195-205.

Fournier, L. R., Scheffers, M. K., Coles, M. G. H., Adamson, A., \& Abad, E. V. (1997). The dimensionality of the flanker compatibility effect: A psychophysiological analysis. Psychological Research, 60, 144-155.

Gratton, G., Coles, M. G. H., \& Donchin, E. (1992). Optimizing the use of information: Strategic control of activation of responses. Journal of Experimental Psychology: General, 121, 480-506.

Lamberts, K. (1994). Towards a similarity-based account of compatibility effects. Psychological Research, 56, 136-143.

Polat, U., \& Sagi, D. (1993). Lateral interactions between spatial channels: Suppression and facilitation revealed by lateral masking experiments. Visual Research, 33, 993-999.

Rösler, F., \& Finger, T. (1993). A psychophysiological analysis of response-channel activation and outcome states in Eriksen's noise-compatibility task. Psychological Research, 55, 20-28.

Rouder, J. N., \& King, J. W. (2003). Flanker and negative flanker effects in letter identification. Perception and Psychophysics, 65, 287-297.

Wolfe, J. M., Friedman-Hill, S. R., Stewart, M. I., \& O'Connell, K. M. (1992). The role of categorization in visual search for orientation. Journal of Experimental Psychology: Human Perception and Performance, 18, 34-49.

— 2009. 10. 30 受稿, 2010.11.13 受理— 